\title{
STUDI FARMAKOVIGILANS PADA PASIEN COVID-19
}

\author{
Sifareina $^{1}$, Ilham Alifiar ${ }^{2 *}$, Muharam Priatna ${ }^{1}$ \\ ${ }^{1}$ Program Studi Farmasi, STIKes Bakti Tunas Husada Tasikmalaya \\ ${ }^{2}$ Program Studi Profesi Apoteker, STIKes Bakti Tunas Husada Tasikmalaya \\ *Email: ilhamalifiar@stikes-bth.ac.id
}

Received: 07/07/2021, Revised: 30/07/2021, Accepted: 04/08/2021, Published: 18/08/2021

\begin{abstract}
ABSTRAK
Coronavirus Disease 2019 (COVID-19) merupakan jenis SARS-CoV baru yang muncul pada bulan Desember tahun 2019 di kota Wuhan, Cina dan menyebar secara luas hampir ke seluruh negara. Jalur penyebaran virus ini sama seperti pada penularan penyakit saluran nafas. Dalam terapi pengobatannya, penyakit COVID-19 ini belum menemukan obat yang spesifik dan baru dalam tahap uji klinis. Terapi yang dilakukan dengan memberikan obat antivirus, dimaksudkan untuk menghambat sel yang terinfeksi dan menghambat virus dalam proses replikasi. Tujuan penelitian ini yaitu untuk mengetahui farmakovigilans dari obat yang dipakai sebagai obat terapi dari penyakit COVID-19 yang didapat dalam jurnal. Dengan metode penelitian secara sistematik literatur dengan menggunakan protokol PRISMA. Kata kunci untuk mendapatkan artikel adalah COVID-19 Pharmacovigilance, Side Effects of COVID-19, Drugs COVID-19 serta menggabungkan AND, OR, dan NOT. Data-base dari empat literatur yaitu PubMed, Europe PMC, Base dan Sciencedirect. Kriteria inklusi dari artikel tahun 2019-2021, berbahasa Indonesia dan Inggris, memiliki isi jurnal yang lengkap, dengan subjek manusia baik perempuan maupun lakilaki dengan golongan semua umur. Dari penelusuran didapatkan hasil sebanyak sebelas jurnal yang masuk kriteria inklusi dengan duabelas obat diantaranya Hydroxychloroquine, Chloroquine, Remdesivir, Azitromisin, Tocilizumab, Lopinavir/Ritonavir, Daruravir/Cobicistat, Ribavirin, Umifenovir, Dan Ceftriaxon, dengan efek samping yang dilaporkan paling banyak yaitu gangguan pada jantung seperti adanya perpanjangan interval QT, gangguan gastrointestinal, peningkatan enzim transminase, gagal hati, gagal ginjal akut, penurunan pendengaran, dan gangguan hepatobilier. Dari sistematik literatur ini, dapat disimpulkan bahwa obat-obat yang digunakan dalam penggunaan terapi COVID-19 menimbulkan berbagai efek samping yang tidak diinginkan sehingga diperlukan pemantauan sebelum dan sesudah terapi seperti pemantauan EKG, pemantauan kadar IL-6, serta pengecekan hasil laboratorium dalam upaya pemantauannya.
\end{abstract}

Kata kunci : COVID-19, Efek Samping, Farmakovigilans.

\section{ABSTRACT}

Coronavirus Disease 2019 (COVID-19) is a new type of SARS-CoV that emerged in December 2019 in the city of Wuhan, China and spread widely in almost all countries. The route of spread of this virus is the same as in the transmission of respiratory diseases. In its treatment therapy, this COVID-19 disease has not yet found a specific drug and is only in the clinical trial stage. 
Therapy is done by giving antiviral drugs, intended to inhibit infected cells and inhibit the virus in the replication process. The purpose of this study was to determine the pharmacovigilance of drugs used as therapeutic drugs for COVID-19 disease obtained in the journal. With a systematic research method literature using the PRISMA protocol. Keywords to get articles are COVID-19 Pharmacovigilance, Side Effects of COVID-19, Drugs COVID-19 and combine AND, OR, and NOT. The databases of four literatures are PubMed, Europe PMC, Base and Sciencedirect. The inclusion criteria for articles for 2019-2021, in Indonesian and English, have complete journal content, with human subjects, both female and male, with all age groups. From the search, it was found that eleven journals entered the inclusion criteria with twelve drugs including Hydroxychloroquine, Chloroquine, Remdesivir, Azithromycin, Tocilizumab, Lopinavir/Ritonavir, Darunavir/Cobicistat, Ribavirin, Umifenovir, and Ceftriaxon, with the most reported side effects being disturbances in Cardiac symptoms such as QT prolongation, gastrointestinal disturbances, elevated transaminase enzymes, liver failure, acute renal failure, hearing loss, and hepatobiliary disorders. From this systematic literature, it can be concluded that the drugs used in the use of COVID-19 therapy cause various unwanted side effects so that monitoring is needed before and after therapy such as ECG monitoring, monitoring IL-6 levels, and checking laboratory results in an effort to monitor them

Keywords: COVID-19, Pharmacovigilance, Side Effect

\section{PENDAHULUAN}

Menurut WHO, Coronavirus Disease 2019 merupakan suatu kelompok virus yang menyebabkan penyakit pada hewan maupun manusia. Coronavirus jenis baru ini dapat menyebabkan suatu wabah/pandemi di berbagai penjuru dunia. Pada tanggal 11 Februari 2020, Coronavirus Disease memiliki nama yang sah yaitu Severe Acute Respitory Syndrome Coronavirus 2 (SARSCoV-2) Karena berasal dari virus bernama Corona Disease 2019 (COVID-19) dan virus baru ini bemula ditemukan di Kota Wuhan, Republik Rakyat Cina yang terjadi pada Bulan Desember 2019 (WHO, 2020)(Jiang et $a l .$, 2020). Hingga saat ini, belum didapatkan obat yang spesifik untuk mengobati penyakit COVID-19. Pengobatan yang dilakukan baru sebatas dalam mengatasi gejala yang timbul pada pasien. Begitu pula dengan vaksin, belum adanya vaksin yang mampu mencegah penyakit COVID-19. Penyakit COVID-19 termasuk penyakit baru, oleh karena itu dalam proses penanganan terapi harus memperhatikan keamanan obat dan potensi Adverse Drug Reaction (ADR). Kemungkinan dalam terjadinya adverse event dengan melibatkan terapi, baik yang bersifat aktual atau potensial dapat mengganggu dalam proses akhir terapi. Salah satunya yaitu ADR yang merupakan suatu respon terhadap obat yang berbahaya dan tidak sengaja serta dapat terjadi pada dosis yang digunakan oleh manusia dalam terapi. Salah satu usaha untuk mengurangi terjadinya hal tersebut, dapat dilakukan dengan dilakukannya studi Farmakovigilans (BPOM, 2020). 
Efek Samping Obat merupakan respon suatu obat yang dapat merugikan yang terjadi pada dosis yang biasa digunakan dalam pencegahan, diagnosis atau terapi penyakit. Akibat dari efek samping tersebut dapat menyebabkan mengancam jiwa atau kematian, perawatan yang lebih lama, menyebabkan kecacatan ataupun kelainan fisik. Sehingga dilakukan mengenai monitoring obat (MESO), yang merupakan bagian dari farmakovigilans. Secara umum farmakovigilans ini bertujuan untuk mencegah terjadinya sebuah kejadian berupa gangguan baik fisik maupun mental yang mungkin ditimbulkan pada manusia akibat penggunaan obat, sehingga didapatkan mengenai profil keamanan obat. Farmakovigilans hampir sama dengan (Nofiarny, 2016; BPOM, 2020).

Dari uraian diatas, diharapakan dapat melakukan monitoring terhadap efek samping ataupun efek yang tidak diinginkan (Adverse Drugs Reaction) pada obat-obatan yang digunakan dalam terapi COVID-19 di Indonesia. Sehingga dalam penggunaan obat dalam terapi pasien COVID-19 didapat obat yang aman dan efektif.

\section{METODE PENELITIAN}

1. Strategi Penelitian / Search Strategy

Penelitian ini merupakan penelitian Systematic Literatur Review (SLR) yaitu suatu metode penelitian dengan melakukan identifikasi, evaluasi, dan telaah terhadap semua hasil penelitian yang relavan terkait dengan pertanyaan penelitian tertentu, topik tertentu, atau suatu fenomena yang menjadi perhatian dari evidence based yang telah dihasilkan sebelumnya. Dengan protokol penelitian yang digunakan yaitu Protokol PRISMA (Preferred Reporting Items for Systematic Reviews and Meta-analyses) yang bersifat sekunder dengan mengikuti protokol atau tahapan penelitian. Metode penelitian ini memiliki prinsip metode penelitian yang merangkum hasil-hasil penelitian primer untuk menyajikan fakta yang lebih komperehensif dan berimbang. Dengan hasil penyajian dapat menjawab pertanyaan dari peneliti (Kitchenham, 2004).

Pada tahapan yang pertama dilakukan yaitu dengan membuat pertanyaan mengenai jurnal atau artikel yang akan di review dengan cara metode "PICO" (Population in Question, Intervention of Interest, Comparator dan Outcome), dengan intervensi pada obat yang digunakan dalam terapi penyakit COVID-19 dan Outcome yang terjadi adanya reaksi yang 
membahayakan seperti efek samping obat, kejadian obat yang merugikan, reaksi obat, kesalahan pengobatan dari obat yang digunakan sebagai terapi COVID-19.

Pada tahap ini juga dilakukan dengan strategi dalam pencarian, menggunakan kata OR dalam menggabungkan kata kunci yang sama atau sinonim, kata AND untuk menggabungkan kata yang berbeda, serta kata NOT untuk memasukan kata yang tidak diinginkan.

Pencarian data mengacu pada database jurnal atau artikel pada PubMed, Sciendirect, Europe PMC, dan Base. Penetapan ini dilakukan untuk memberikan batasan wilayah dalam mencari hasil penelitian yang relavan.

\section{Inclusion and Exclusion}

a. Kriteria Inklusi

Jurnal tahun 2019-2021, kata kunci yang digunakan diantaranya COVID-19 Pharmacovigilans, Side Effects of COVID19, dan Drugs COVID-19, menggunakan Bahasa Inggris maupun bahasa Indonesia dengan isi yang full-text (abstrak, introduction, metode, hasil dan pembahasan, kesimpulan dan daftar pustaka), dengan subjek penelitian yang dilakukan pada manusia, baik wanita mapun laki-laki dengan semua golongan umur yang terinfeksi virus COVID-19.

\section{b. Kriteria Ekslusi}

Jurnal atau artikel yang tidak lengkap (tidak memiliki asbtrak, metode, hasil dan kesimpulan), tidak dalam bahasa Inggris maupun bahasa Indonesia, jurnal atau artikel dibawah tahun 2019 dan diatas tahun 2020, tidak membahas mengenai terapi COVID-19 serta jurnal atau artikel yang tidak sesuai dengan tema.

3. Ekstraksi Data

Tahapan ini dilakukan dalam mengumpulkan informasi data yang terdapat dalam jurnal/artikel dengan mengsinkronkan dengan pertanyaan yang telah ditentukan sebelumnya.

4. Penyajian Data

Hasil disajikan dalam bentuk dokumen laporan hasil systematic review dengan menyajikan kajian penting dalam jurnal yang didapat seperti obat yang digunakan, efek samping yang terjadi, dan jumlah subjek yang terlibat.

\section{HASIL DAN PEMBAHASAN}

Penelitian ini merupakan Systematic Literature Review (SLR), yang memiliki tujuan untuk mengetahui farmakovigilans dari obat-obat yang dipakai sebagai terapi yang digunakan pada COVID-19 dengan mencari literatur-literatur yang sebelumnya telah ditentukan terlebih dahulu mengenai 
kriteria-kriterianya, dengan hasil data yang termasuk ke dalam analisis meta-syntesis atau naratif. Pengambilan sumber literatur dari yang didapat adalah Sciendirect, PubMed, Europe PMC, dan Base dengan desain penelitian yang didapatkan mengenai cohort. Pengambilan atau penulurusan data dilakukan dalam kurun waktu dari bulan Maret sampai bulan April 2021, dengan jumlah artikel/jurnal yang didapatkan sebanyak sebelas.

Hasil dari kata kunci yang telah ditentukan, didapat sebanyak 91.078 artikel/jurnal dari ke empat data-base dengan proses yang dilakukan yaitu identifikasi, sehingga diperoleh kata kunci untuk pencarian literatur pada data-base. Setelah dilakukan identifikasi, proses selanjutnya dilakukan proses skrining terhadap jurnaljurnal yang telah didapat. Skrining dapat dilakukan dengan proses penyaringan atau pemilihan data dengan tujuan untuk memilah milih sesuai dengan masalah penelitian yang telah ditentukan. Skrining dapat dilakukan dengan berbagai cara, diantaranya dengan membaca judul/title terlebih dahulu dan memasukan kriteria inklusi dan ekslusi terhadap jurnal/artikel. Dengan jumlah yang termasuk ke dalam kriteria ekslusi sebanyak 61.223 jurnal. Hasil dari skrining didapatkan sebanyak empat belas jurnal/artikel dengan perolehan masing-masing data-base yaitu PubMed satu, Base enam, Europe PMC enam, dan Sciendirect satu. Selanjutnya, setelah proses skrining maka dilanjutkan dengan proses eligibility/kelayakan yaitu dengan cara menjawab pertanyaan yang telah ditentukan sebelumnya. Proses ini dilakukan dengan memasukan data artikel/jurnal yang layak untuk masuk tahap/proses selanjutnya, pada tahap ini didapat sebanyak sebelas jurnal yang masuk dalam proses eligibility dari ke empat data-base yang ada. Proses terakhir dilakukan dengan cara include/termasuk ke dalam artikel/jurnal yang layak untuk masuk tahap ekstraksi data dan artikel/jurnal hasil tahap eligibility masuk semua ke dalam proses include dapat dilihat pada Gambar 1. 


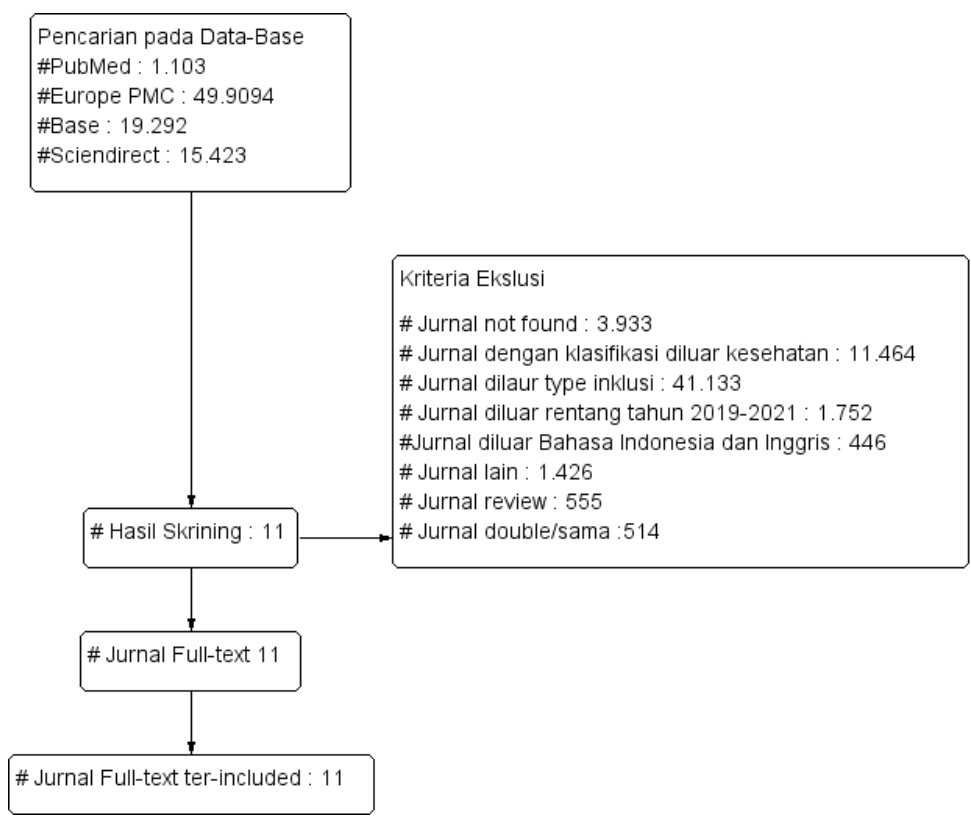

Gambar 1. Hasil PRISMA

Tabel 1. An overview of the 11 Studies for the systematic review

\begin{tabular}{|c|c|c|c|c|}
\hline Title & Location & Study Objective & $\begin{array}{l}\text { Type of } \\
\text { Study }\end{array}$ & $\begin{array}{c}\text { Data } \\
\text { Collection } \\
\text { and } \\
\text { Analythical } \\
\text { Type }\end{array}$ \\
\hline $\begin{array}{l}\text { A Prospective, Observational Study To Evaluate Adverse } \\
\text { Drug Reactions In Patients With COVID-19 Treated With } \\
\text { Remdesivir Or Hydroxychloroquine : A Preliminary Report }\end{array}$ & Italy & $\begin{array}{l}\text { mengevaluasi reaksi } \\
\text { obat yang } \\
\text { merugikan (ADR) } \\
\text { yang dikaitkan } \\
\text { dengan REM atau } \\
\text { hydroxychloroquine } \\
\text { (HCQ) pada pasien } \\
\text { yang dirawat di } \\
\text { rumah sakit karena } \\
\text { COVID-19 }\end{array}$ & $\begin{array}{l}\text { Kohort } \\
\text { Retrospektif }\end{array}$ & kuantitatif \\
\hline $\begin{array}{l}\text { Adverse Drug Reactions In SARS-Cov-2 Hospitalised } \\
\text { Patients : A Case-Series With A Focus On Drug-Drug } \\
\text { Interactions }\end{array}$ & Italy & $\begin{array}{l}\text { mendeskripsikan } \\
\text { karakteristik klinis } \\
\text { dan farmakologis } \\
\text { pasien SARS-CoV-2 } \\
\text { yang dirawat di rumah } \\
\text { sakit, dengan fokus } \\
\text { pada ADR }\end{array}$ & Observasi & kualitatif \\
\hline $\begin{array}{l}\text { Assessing QT Interval In COVID-19 Patients : Safety Of } \\
\text { Hydroxychloroquine - Azithromycin Combination Regimen }\end{array}$ & Italy & $\begin{array}{l}\text { menilai efek obat } \\
\text { Hydroxychloroquine } \\
\text { dan azithromycin } \\
\text { terhadap interval QT } \\
\text { pada COVID-19 }\end{array}$ & $\begin{array}{l}\text { Kohort } \\
\text { Resrospektif }\end{array}$ & Kuantitatif \\
\hline $\begin{array}{l}\text { Assessment Of COVID-19 Treatment Containing Both } \\
\text { Hydroxychloroquine And Azithromycin: A Natural Clinical } \\
\text { Trial }\end{array}$ & Irak & $\begin{array}{l}\text { Menilai efektivitas } \\
\text { klinis dan profil } \\
\text { keamanan pengobatan } \\
\text { COVID-19 } \\
\text { menggunakan } \\
\text { hydroxychloroquin } \\
\text { dan azitromisin }\end{array}$ & $\begin{array}{l}\text { Kohort } \\
\text { Resrospektif }\end{array}$ & kuantitatif \\
\hline
\end{tabular}


Hydroxychloroquine And Azithromycin As A Treatment Of COVID-19 : Electrocardiogram Variability

Incidence Of Suspected Serious Adverse Drug Reactions In Corona Virus Disease-19 Patients Detected By A Pharmacovigilance Program By Laboratory Signals In A Tertiary Hospital In Spain: Cautionary Data

Pharmacotherapy Management For COVID-19 And Cardiac Safety: A Data Mining Approach For Pharmacovigilance Evidence From The FDA Adverse Event Reporting System (FAERS)

Plasma Concentrations And Safety Of lopinavir/Ritonavir In COVID-19 Patients

Spontaneous Reported Cardiotoxicity Induced By lopinavir/Ritonavir In COVID-19. An Alleged Past-Resolved Problem

Tocilizumab Combined With Favipiravir In The Treatment Of COVID-19: A Multicenter Trial In A Small Sample Size
Maroko

mendeskripsikan efek

kardiovaskular pada

Observasi

Kohort

obat

hydroxychloroquin

dan azitromisin

dengan menganalisis

EKG pasien COVID

19

Michigan

mengkarakterisasi

perpanjangan

Kohort

pada pasien rawat inap

dengan penyakit

COVID-19 dengsn

terapi

hydroxychloroquine

dan azithromycin

Spanyol

melaporkan dugaan

reaksi obat yang

merugikan serius

(SADR) pada pasien COVID-19 vs pasien non-COVID-19

Cina

menyelidiki risiko

efek samping jantung pada pasien COVID

19 dengan terapi oba

antimalaria, antivirus,

dan antibiotik tertentu

Paris

Mengetahui

keamanan obat

lopinavir/ritonavir

pada pasien COVID-

19

Prancis

Mengkarakterisasi

secara kualitatif

kardiotoksisitas yang

berkaitan dengan obat

lopinavir/ritonavir

pada pasien COVID-

19

Cina

menilai kemanjuran

dan keamanan

tocilizumab yang

dikombinasikan

dengan favipiravir

pada pasien dengan

COVID-19
Kohort

Kohort

Prospektif

Kohort

Resrospektif

Kohort

Resrospektif

Kohort kuantitatif

kuantitatif

Kuantitatif

Kualitatif

kuantitatif

kuantitatif

kuantitatif

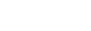

Tabel 2. Ekstraksi Data Secara Spesifik terkait metode penelitian

\begin{tabular}{|c|c|c|c|}
\hline $\begin{array}{c}\text { Jumlah sampel yang } \\
\text { digunakan }\end{array}$ & $\begin{array}{c}\text { Sampel yang } \\
\text { digunakan }\end{array}$ & $\begin{array}{c}\text { Metode } \\
\text { penelitian }\end{array}$ & Obat \\
\hline 149 & Manusia & $\begin{array}{l}\text { Kohort } \\
\text { Retrospektif }\end{array}$ & $\begin{array}{l}\text { Chloroquine } \\
\text { /Hydroxychloroquin } \\
\text { Remdesivir } \\
\text { Azitromisin }\end{array}$ \\
\hline
\end{tabular}


Manusia Observasi

112

161

118

415

575

311

31

176

26
Manusia

Manusia

Kohort

Resrospektif

Manusia

Kohort

Resrospektif

Observasi

Kohort

Manusia

Manusia

Manusia

Kohort

Resrospektif

Kohort
lopinavir/Ritonavir

Chloroquine

/Hydroxychloroquin

Darunavir/ Cobicistat

lopinavir/Ritonavir

Azitromisin

Toclizumab

Chloroquine

/Hydroxychloroquin

Azitromisin

Chloroquine

/Hydroxychloroquin

Azitromisin

Chloroquine

/Hydroxychloroquin

Azitromisin

Hydroxychloroquin

Azitromisin

Hydroxychloroquin

Azitromisin.

lopinavir/Ritonavir

Ceftriaxone

Tocilizumab.

Chloroquine/

Hydroxychloroquine

Azitromisin

Lopinavir / Ritonavir

Ribavirin

Umifenovir

Azitromisin

Ceftriaxone

Lopinavir / Ritonavir

Lopinavir / Ritonavir

Faviravir

Tocilizumab

Tabel 3. Rangkuman Isi Jurnal

\begin{tabular}{ll}
\hline \multicolumn{1}{c}{ Judul } & \multicolumn{1}{c}{ Isi } \\
\hline A Prospective, Observational Study To Evaluate Adverse Drug & Jurnal berisi evaluasi mengenai reaksi obat yang merugikan pada \\
Reactions In Patients With COVID-19 Treated With Remdesivir Or & pasien COVID-19 dengan terapi pengobatan yang diterima yaitu \\
Hydroxychloroquine : A Preliminary Report & remdesivir atau hydroxychloroquine. Penelitian ini dilakukan pada \\
& tanggal 15 Maret sampai 15 Agustus 2020 dengan sampel yang \\
& didapat sebanyak 149 peserta, yang dikelompokan menjadi dua \\
& kelompok. Kelompok pertama sebanyak 101 menggunakan obat \\
& hydroxychloroquine (HCQ) dengan dosis pada hari ke-1 sebesar 400
\end{tabular}


Adverse Drug Reactions In SARS-Cov-2 Hospitalised Patients : A Case-Series With A Focus On Drug-Drug Interactions

Assessing QT Interval In COVID-19 Patients : Safety Of Hydroxychloroquine - Azithromycin Combination Regimen

Assessment Of COVID-19 Treatment Containing Both Hydroxychloroquine And Azithromycin: A Natural Clinical Trial

Hydroxychloroquine And Azithromycin As A Treatment Of COVID-19 : Electrocardiogram Variability

Hydroxychloroquine/Azithromycin Therapy And QT Prolongation In Hospitalized Patients With COVID-19

Incidence Of Suspected Serious Adverse Drug Reactions In Corona Virus Disease-19 Patients Detected By A Pharmacovigilance Program By Laboratory Signals In A Tertiary Hospital In Spain: Cautionary Data

Pharmacotherapy Management For COVID-19 And Cardiac Safety: A Data Mining Approach For Pharmacovigilance Evidence From The FDA Adverse Event Reporting System (FAERS) mg dan 200 mg selama 5-10 hari, sedangkan pada kelompok kedua sebanyak 48 peserta menggunakan obat remdesivir (REM) dengan dosis $200 \mathrm{mg}$ pada hari ke-1 dan dilanjutkan dengan dosis $100 \mathrm{mg}$ selama 5-10 hari. Dari 149 peserta, sebanyak 54 peserta mengalami seperti gangguan hepatobilier, gangguan gastrointestinal, gangguan ginjal, dan jantung. Dengan perbandingan lebih banyak ADR pada kelompok HCG dibanding dengan pengobatan REM.

Penelitian ini dilakukan pada tanggal 1 januari sampai 31 mei 2020 di Italia dengan melibatkan 23 pasien yang mengalami ADR, dengan pengobatan yang diberikan yaitu obat HCQ dengan dosis $800 \mathrm{mg}$ pada hari pertama dan diikuti $400 \mathrm{mg} /$ hari selama 5-7 hari, atau dikombinasikan dengan lopinavir/ritonavir 400/100 mg dua kali sehari, serta dengan kombinasi antibiotik azitromisin $500 \mathrm{mg}$ pada hari pertama dan $250 \mathrm{mg} /$ hari selama 3-4 hari, dan dengan kombinasi darunavir / cobicistat $800 / 150 \mathrm{mg} /$ hari. ADR yang timbul diantaranya satu pasien mengalami peningkatan transminase, tiga pasien menunjukan gangguan gastrointetinal, delapan belas pasien mengalami kardiovaskular, satu pasien menunjukan adanya perpanjangan interval QT dan satu mengalami psikotik.

Penelitian yang melibatkan sebanyak 112 pasien ini dibagi menjadi 3 kelompok, yaitu kelompok tanpa pengobatan, kelompok dengan pengobatan HCQ, dan kelompok kombinasi HCQ dengan AZT. Dengan hasil pada kelompok dua dan tiga memiliki perpanjangan interval QT tetapi tidak dalam kurun waktu yang lama dan tidak menimbulkan kematian.

Penelitian dengan melibatkan 161 peserta, dengan penggunaan obat HCQ dan AZT, dengan efek samping yang sering dilaporkan yaitu terjadinya sakit perut/kram, hipoglikemia, sakit kepala, perubahan mood, pusing, datal, diare, nyeri otot, kelemahan, mual, ruam kulit, muntah, perpanjangan QT, aritmia, dan konjungtiva. Dengan hasil EKQ dari enam pasien mencatat adanya perpanjangan QTc dan tiga pasien megalami aritmia.

Penelitian ini melibatkan 118 pasien dengan obat yang digunakan yaitu HCQ dan AZT, dengan beberapa pasien mengalami penyakit kormodibitas atau penyakit penyerta. Dengan hasil ekg menunjukan 23 pasien adanya perpanjangan interval QT pada kombinasi, peningkatan QTc lebih dari $40 \mathrm{~ms}$ pada 18 pasien dengan kormodibitas kardiovaskular dengan waktu muncul setelah dua hari pengobatan. Pada empat pasien mengalami gangguan irama jantung. Sembilan belas persen pasien mengalami gangguan repolarisasi dan terjadinya kelainan morfologis.

Pengobatan yang dilakukan menggunakan HCQ dan AZT dengan melibatkan sebanyak 415 pasien memiliki data lengkap. Dengan hasil nilai pada interval QTc meningkat karena adanya pemberian obat tersebut.

Sebanyak 575 pasien dengan positif COVID-19, dengan rentang waktu penelitian 1 Maret hingga April 2020, penelitian ini membandingkan dengan pasien non COVID-19. Pasien dengan COVID-19 memiliki efek ADRS 3x lebih tinggi dibanding pasien non COVID-19

Penelitian dengan melibatkan 311 pasien ini melaporkan sebanyak 26 pasien melaporkan terjadinya gangguan jantung. Gangguan kardiak AE terjadi pada obat Hydroxychloroquine/ chloroquine, Lopinavir / Ritonavir, Ribavirin, Umifenovir, Azitromisin, Ceftriaxone sebanyak 26 pasien. Dengan AE yang dilaporkan paling banyak yaitu serangan jantung, takikardi, perpanjanganinterval QT. Kombinasi antara Hydroxychloroquine/ chloroquine dengan azitromisin mengakibatkan serangan jantung dan perpanjngan interval QT dilaporkan. 
Plasma Concentrations And Safety Of lopinavir/Ritonavir In COVID19 Patients

Spontaneous Reported Cardiotoxicity Induced By lopinavir/Ritonavir In COVID-19. An Alleged Past-Resolved Problem

Tocilizumab Combined With Favipiravir In The Treatment of COVID-19: A Multicenter Trial In A Small Sample Size

Sebanyak 31 pasien posotof COVID-19, dengan rentang waktu 18 Maret sampai 1 April 2020 penelitian ini dilakukan dengan terapi yang digunakan yaitu obat Lopinavir/Ritonavir, dosis yang digunakan 400/100 mg diberikan dua kali sehari dengan lama pemberian 8 hari. ADR yang dilaporkan yaitu 4 kasus gangguan hati, 2 kasus gangguan cerna, dan satu kasus gangguan jiwa (agitasi/kecemasan)

176 kasus kardiosisitas yang dilakukan selama 8 minggu sejak 1 Mare 2020, dengan 22 kasus dikaitkan dengan terapi menggunakan obat Lopinavir/Ritonavir. Pada 17 kasus mengakibatkan perpanjangan interval QT dan 5 kasus menyebabkan aritmia ventrikel, dengan mekanisme yang diduga bahwa obat tersebut dapat memblokir saluran ionik hingga terjadinya penghambatan hERG.

Penelitian yang dilakukan pada 2 Februari sampai 15 Maret 2020, dengan jumlah pasien sebanyak 26 dan dikelompokan menjadi 7 pasien dalam kelompok faviravir, 5 pasien kelompok tocilizumab dan 14 pasien dengan kombinasi kedua obat tersebut. Dua kasus reaksi yang merugikan terjadi pada masing masing kelompok faviravir dan kelompok kombinasi tocilizumab melaporkan terjadinya peningkatan transaminase, diare dan hiperurisemia.

Pada Tabel 1, di dapat bahwa hasil dari ekstraksi secara general sebelas jurnal, di dapat jurnal dengan penelitian dari berbagai negara. Dari beberapa negara tersebut didapat bahwa penelitian yang dilakukan dengan metode kohort/cohort yaitu penelitian yang mempelajari hubungan antara papara dan penyakit dengan membandingkan kelompok yang terpapar dengan yang tidak (Irmawartini \& Nurhaedah, 2017). Pada negara Italy, didapat tiga jurnal dengan dua jurnal yang membahas mengenai reaksi obat yang merugikan pada pasien COVID-19 dengan pengobatan, pada satu jurnal yang membahas mengenai rejimen keamanan obat hydroxychloroquine yang kombinasi dengan azitomicin. Pada jurnal yang didapat pada negara Irak, membahas mengenai penilain pengobatan hydroxychloroquine dan azitromicin pada penyakit COVID-19. Selanjutnya pada negara Maroko dan Michigan didapat jurnal dengan obat yang efek pengobatan COVID-19 mengenai jantung, dengan pengobatan yang diberikan yaitu hydroxychloroquine serta azitromicin. Negara Cina didapat sebanyak dua jurnal membahas mengenai manajemen farmakoterapi pada COVID-19 dan keamanan jantung dan pengobatan yang diberikan obat Tocilizumab yang dikombinasikan dengan faviravir. Pada negara Spanyol didapat jurnal yang membahas mengenai insiden reaksi yang merugikan pada pasien positif COVID-19 dengan data yang ada. Sedangkan pada kedua jurnal yang diambil dari negara Paris dan Prancis membahasa mengenai pengobatan pasien COVID-19 dengan Lopinavir/Ritonavir. 
Pada Tabel 2, dari sebelas jurnal yang didapat bahwa delapan jurnal menggunakan obat hydroxychloroquine dan azitomicin, enam jurnal menggunakan obat lopinavir/ritonavir, tiga jurnal menggunakan tocilizumab, satu jurnal menggunakan obat darunavir/cobicistat, ceftriaxone, dan umifenovir. Dengan sampel yang digunakan pada seluruh jurnal pada manusia yang dirawat di Rumah Sakit dan positif terkena virus COVID-19 dan jumlah peserta dengan reantang 23 sampai 575 pasien yang terlibat.

Pada kesebelas jurnal ini, di dapat outcome atau informasi mengenai efek samping atau reaksi efek yang tidak diinginkan (Adverse Drug Reaction) yaitu adanya gangguan pada jantung dnegan menimbulkan perpanjangan interval QT, diantaranya yang paling banyak ditimbulkan pada jurnal yang ditulis oleh Crescioli et al (2020), Bernardini et al (2020), Abbas et al (2020), El Ouarradi et al (2020), Yuan et al (2021), Zhao et al (2020). Dengan obat yang dilaporkan memiliki efek tersebut yaitu pada obat hydroxychloroquin / chloroquine, azitromicin, lopinavir/ritonavir. Interval QT merupakan urutan dari hasil pemeriksaan elektrokardiogram (EKG) dari awal kompleks QRS ke akhir gelombang T serta mewakili yang setara dengan temporal depolarisasi ventrikel dan repolarisasi. 204
Dengan nilai koreksi untuk denyut jantung disebut sebagai interval QTc. Pada perpanjangan interval QTc ini dianggap sebuah penanda dari potensi dari obat khusus yang terkait dalam peningkatan risiko takikardia ventrikel Torsade "Torsade de Pointes" (TdP) yang mengarah kepada kematian mendadak. Dengan nilai interval QT normal pada laki-laki memiliki interval QT normal adalah kurang dari $450 \mathrm{~ms}$, sedangkan pada wanita $460 \mathrm{~ms}$ dan batas minimalnya yaitu $390 \mathrm{~ms}$ (Yofrido et al., 2018). Selain adanya perpanjangan interval QT pada gangguan jantung, terjadi juga adanya takikardi atau peningkatan denyut jantung lebih dari 100 kali permenit, fibrilasi atrium yang merupakan gangguan irama dengan karakteristik aktivasi elektrik atrium tidak teratur dan kontraksi atrium tidak terkoordinasi.

Efek samping yang dilaporkan lainya yaitu gangguan hepatobillier, dari sebelas jurnal yang melaporkan adanya efek samping ini hanya satu jurnal yang ditulis oleh Falcão et al (2021) dengan obat yang dilaporkan yaitu hydroxychloroquin /chloroquine, remdesivir, lopinavir/ritonavir, dan azitromicin. Pada jurnal, gangguan hepatobillier diidentifikasi dengan adanya peningkatan enzim transmirase, bilirubin, dan GGT. Enzim transaminase meliputi 
enzim alanine transaminase (ALT) atau serum glutamate piruvat transferase (SGPT) dan aspartate transaminase (AST) atau serum glutamate oxaloacetate transferase (SGOT). Pengukuran aktivitas SGPT dan SGOT serum dapat menunjukkan adanya kelainan sel hati tertentu, meskipun bukan merupakan uji fungsi hati sebenarnya pengukuran aktivitas enzim ini tetap diakui sebagi uji fungsi hati. Enzim ALT/SGPT terdapat pada sel hati, jantung, otot dan ginjal. Tingginya kadar AST/SGOT berhubungan langsung dengan jumlah kerusakan sel. Pada peningkatan kadar bilirubin lebih dari 3 $\mathrm{mg} / \mathrm{dL}$ biasanya baru dapat menyebabkan ikterus. Ikterus mengindikasikan gangguan metabolisme bilirubin, gangguan fungsi hati, penyakit bilier, atau gabungan ketiganya. Sedangkan enzim Gamma GT terdapat di sel hati, ginjal, dan pankreas. Pada sel hati gamma GT terdapat di retikulum endoplasmik sedangkan di empedu terdapat di sel epitel.

Pada efek samping yang dilaporkan lainnya yaitu adanya gangguan gastrointestinal atau gangguan pencernaan yang timbul seperti mual, muntah, dan diare. Efek samping ini paling umum muncul dari berbagai obat lainnya, dengan obat yang dilaporkan yaitu pada obat-obat hydroxychloroquin/chloroquine,azitromicin, lopinavir/ritonavir yang ditulis oleh Falcão et al (2021), Crescioli et al (2020), dan Abbas et al (2020).

Gagal ginjal, merupakan salah satu dari sekian efek samping yang dilaporkan pada jurnal yang ditulis oleh Falcão et al (2021), pada obat obat hydroxychloroquin/ chloroquine, azitromicin. Selain itu, efek samping dengan gangguan kejiwaan dilaporkan pada jurnal yang ditulis Chouchana et al (2021) dan Crescioli et al (2020) menyebutkan gangguan kejiwaan yang ditimbulkan yaitu agitasi atau kecemasan dengan tingkat ringan dengan obat yang dicurigai yaitu hydroxychloroquin, darunavir/cobicistat, tocilizumab dan lopinavir/ritonavir. Tidak hanya dari efek samping obat, gangguan kecemasan juga dapat timbul dari penyakit COVID-19 dapat menyebabkan depresi, dan kecemasan. Selain itu, efek samping pada penurunan pendengaran yang ditimbulkan oleh obat umifenovir yang dilaporkan oleh Yuan et al (2021) pada jurnalnya tetapi tidak dijelaskan bagaimana itu bisa terjadi.

\section{KESIMPULAN}

Dapat disimpulkan bahwa dalam penelitian sistematik review ini, merupakan hasil akhir dengan cara analisis metasintesis atau naratif. Obat-obat yang banyak 
digunakan dalam terapi pengobatan penyakit COVID-19 diantaranya mampu menimbulkan efek samping yang tidak diinginkan seperti gangguan pada jantung diantaranya perpanjangan interval QT, takikardi, fibrilasi atrium, serangan jantung dilaporkan ditimbulkan oleh obat hydroxychloroquin/chloroquine,

azitromicin, lopinavir/ritonavir. Pada gangguan gastrointestinal dilaporkan pada obat hydroxychloroquin / chloroquine, azitromicin, lopinavir/ritonavir. Efek samping gangguan hepatobiliary dilaporkan oleh obat hydroxychloroquin /chloroquine, remdesivir, lopinavir/ritonavir, dan azitromicin. Pada gagal ginjal akut dilaporkan oleh obat hydroxychloroquin/ chloroquine, azitromicin., gangguan kejiwaan oleh obat hydroxychloroquin, darunavir/cobicistat, tocilizumab dan lopinavir/ritonavir serta penurunan pendengaran dilaporkan oleh obat umifenovir. Sehingga perlu dilakukan pemantauan terapi sebelum dan sesudah pemberian obat, seperti pemantauan EKG pada pasien pada pasien yang mengalami efek samping gangguan jantung, pemantuan hati, ginjal pada pasien dengan efek samping peningkatan enzim transminse, serta pengecekan hasil labolatorium dalam upaya pemantuannya. Laporan mengenai 206 farmakovigilans ini memberikan manfaat bagi informasi obat dalam pemantauan efek samping yang mungkin terjadi diantar negara agar berantisipasi dalam pengobatanya.

\section{DAFTAR PUSTAKA}

Abbas, H. M., Al-Jumaili, A. A., Nassir, K. F., Al-Obaidy, M. W., Al Jubouri, A. M., Dakhil, B. D., Abdulelah, M. M., \& Al Khames, Q. A. (2020). Assessment of COVID-19 Treatment Containing Both Hydroxychloroquine and Azithromycin: A Natural Clinical Trial. International Journal of Clinical Practice, $\quad 75(4)$, 1-9. https://doi.org/10.1111/ijcp.13856

Badan Pengawas Obat dan Makanan. (2020). Modul Farmakovigilans Dasar.

Bernardini, A., Ciconte, G., Negro, G., Rondine, R., Mecarocci, V., Viva, T., Santini, F., \& Innocentiis, C. De. (2020). Assessing QT Interval in COVID-19 Patients: Safety of Hydroxychloroquine- Azithromycin Combination Regimen. International Journal of Cardiology, 324, 242-248. https://doi.org/https://doi.org/10.1016/ j.ijcard.2020.09.038 0167-5

BPOM. (2020). Informatoirum Obat Covid19 di Indonesia (B. P. O. \& M. R. Indonesia (ed.); Pertama). Badan 
Pengawas Obat \& Makanan Republik Indonesia.

online.flipbuilder.com/tbog/infi/mobil e/index.html

Chouchana, L., Boujaafar, S., Gana, I., Preta, L. H., Regard, L., Legendre, P., Azoulay, C., Canouï, E., Zerbit, J., Carlier, N., Terrier, B., Kernéis, S., Batista, R., Treluyer, J. M., Zheng, Y., \& Benaboud, S. (2021). Plasma Concentrations and Safety of Lopinavir/Ritonavir in COVID-19 Patients. Therapeutic Drug Monitoring, 43(1), 131-135. https://doi.org/10.1097/FTD.0000000 000000838

Crescioli, G., Brilli, V., Lanzi, C., Burgalassi, A., Ieri, A., Bonaiuti, R., Romano, E., Innocenti, R., Mannaioni, G., Vannacci, A., \& Lombardi, N. (2020). Adverse Drug Reactions In SARS Cov 2 Hospitalised Patients: A Case Series With A Focus On DrugDrug Interactions. Internal and Emergency Medicine. https://doi.org/https://doi.org/10.1007/ s11739-020-02586-8

El Ouarradi, A., Abdeladim, S., Oualim, S., Aniq Filali, R., Elharass, M., Hafid, S., Tazi, H., Naitlhou, A., Bouaiti, E. L. A., Moustaghfir, A., \& Sabry, M.
(2020). Hydroxychloroquine and Azithromycin as a Treatment of COVID-19: $\quad$ Electrocardiogram Variability. Journal of the Saudi Heart Association, $\quad 32(3), \quad 350-357$. https://doi.org/10.37616/2212-

5043.1088

Falcão, F., Viegas, E., Carmo, I., Soares, J., Falcao, M., Solano, M., Cavaco, P., Mendes, D., Rijo, J., Povoa, P., Pais Martins, A., Carmo, E., Mansinho, K., Fonseca, C., Campos, L., Carvalho, A., Mirco, A., Farinha, H., Aldir, I., \& Correia, J. (2021). A Prospective, Observational Study to Evaluate Adverse Drug Reactions in Patients With COVID-19 Treated with Remdesivir or Hydroxychloroquine: A Preliminary Report. European Journal of Hospital Pharmacy, 1-6. https://doi.org/10.1136/ejhpharm2020-002613

Irmawartini, \& Nurhaedah. (2017). Metodologi Penelitian (1st ed.). Kementrian Kesehatan Republik Indonesia.

Jiang, Y., Yin, W., \& Xu, H. E. (2020). RNADependent RNA Polymerase: Structure, Mechanism, and Drug Discovery for COVID-19. Biochemical and Biophysical Research 
Communications, $\quad x x x x$. https://doi.org/10.1016/j.bbrc.2020.08. 116

Kitchenham, B. (2004). Procedures for Performing Systematic Reviews. In K. U. T. R. TR (Ed.), Department of Computer Science (Issue 1). Keele University Technical.

Nofiarny, D. (2016). Pengenalan Farmakovigilans: Apa dan Mengapa Diperlukan? Medicinus, 29(April), $53-56$.

World Health Organization. (2020). No Title. In World Health Organization.

Yofrido, F. M., Christine, I., \& Harjana, L. T. (2018). Pemanjangan Interval Qt Terkoreksi (Qtc) Pada Pasien Hipokalemia Berat Dengan Penyulit Aritmia Ventrikel Fatal. Jurnal Widya Medika, 4(2), 106-113.

Yuan, J., Li, M., Yu, T. L., Lv, B., Han, B., Xiang, X., \& Lu, Z. K. (2021). Pharmacotherapy Management for COVID-19 and Cardiac Safety: A Data Mining Approach for Pharmacovigilance Evidence from the FDA Adverse Event Reporting System (FAERS). Original Research Article Pharmacotherapy. https://doi.org/https://doi.org/10.1007/ s40801-021-00229-8 Zhao, H., Zhu, Q., Zhang, C., Li, J., Wei, M., Qin, Y., \& Chen, G. (2020). Tocilizumab Combined With Favipiravir In The Treatment of COVID-19: A Multicenter Trial in a Small Sample Size. Biomedicine \& Pharmacotherapy, 133(110825), 1-7. 